\title{
Prosthetic valve endocarditis: a review of 24 cases
}

\author{
IAN S. PETHERAM AND J. M. H. BOYCE ${ }^{1}$ \\ From Sully Hospital, Sully, South Glamorgan, and St David's Hospital, Cardiff
}

Petheram, I. S. and Boyce, J. M. H. (1977). Thorax, 32, 478-485. Prosthetic valve endocarditis: a review of 24 cases. Twenty-four episodes of prosthetic valve endocarditis occurred in 23 patients in a 10-year period. Fifteen patients presented within four months and nine from 14 months to seven years after surgery. The commonest pathogens in the early group were Candida albicans (five), but in three of these patients other organisms were found; diphtheroid species in five and Staphylococcus aureus in three. Four patients in the late group had Streptococcus viridans infection. Antistaphylococcal operative prophylaxis has been successful, but opportunist organisms of low virulence in health have emerged as pathogens. Continuous monitoring of antibiotic prophylaxis may reduce the incidence of early cases, and antibiotic cover for dental procedures should be as meticulous after valve replacement as before operation. The most frequent cause of death in both groups was delayed or inadequate treatment because of failure to isolate the pathogens from blood cultures with consequent severe haemodynamic upset or uncontrolled infection. Previous courses of antibiotics were the usual reason for negative blood cultures. Successful management requires close liaison with an interested clinical bacteriologist and aggressive surgery for haemodynamic faults or failure to control infection.

Since the onset of cardiac valve replacement, prosthetic endocarditis shortly after operation has been an important, life-threatening complication (Denton et al., 1957). The incidence was 7-12\% (Lord et al., 1961; Stein et al., 1966) before the introduction of non-wettable sutures; shorter operating times and routine antistaphylococcal antibiotic prophylaxis reduced the rate of infection to $1-2 \%$ (Stein et al., 1966).

More recently, a separate group of patients has been identified, presenting late after surgery with a bacteriological spectrum similar to classical infective endocarditis and with a better prognosis (Shafer and Hall, 1970; Block et al., 1970; Dismukes et al., 1973; Slaughter et al., 1973).

Although Stein et al. (1966) suggested that prosthetic valve endocarditis occurring soon after cardiac surgery could be virtually eliminated by suitable antibiotic prophylaxis, cases continue to occur. Because the management of these patients is difficult and the mortality remains considerable, this paper reviews a 10-year experience at a regional cardiothoracic centre.

'Present address: East Glamorgan Hospital, Pontypridd, Mid Glamorgan

\section{Patients and methods}

For inclusion in this series one of the following criteria was required:

1 positive blood cultures in the presence of suggestive clinical features such as splenomegaly, $\underset{x}{\times}$ emboli, new murmurs or unexplained heart $\frac{0}{3}$ failure;

2 recovery of organisms from the prosthesis at 8 necropsy;

3 demonstration at necropsy or surgery of typi-윽 cal vegetations.

Patients from whom no organism could be cul-o tured and who were given 'blind' antibiotic therapy with apparent recovery have not been included.

In the 10-year period $1966-1975,940$ operations 0 for cardiac valve replacement were performed at $\mathrm{\omega}_{\mathrm{E}}$ the cardiothoracic centre for South Wales whicho was situated at Sully Hospital up to mid 1972 ando subsequently at the University Hospital of Wales. Eight-hundred-and-fifty-one single valve replace-? ments, 79 double, and 10 triple replacements were 0 performed and a total of 1039 prosthetic valves

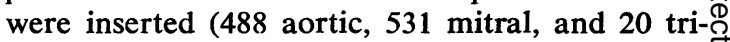
cuspid prostheses). Routine parenteral antibiotic $\stackrel{\mathbb{\Omega}}{\Omega}$ prophylaxis was started 24 hours preoperativelyo 
and continued during bypass and for five to seven days postoperatively. The drugs used, principally antistaphylococcal agents, were prescribed by the surgical teams, and there was some variation in the regimes selected. Further antibiotics were prescribed as necessary according to the clinical and bacteriological condition of the patient. No routine antifungal agents were given. Anticoagulants were started on the third or fourth postoperative day when drainage tubes were removed.

All patients with suspected infective endocarditis were investigated routinely by blood samples cultured in glucose broth, heart-brain infusion broth, and Robertson's cooked meat medium both aerobically and anaerobically and, if negative, cultures were set up in Sabouraud's medium at room temperature and at $37^{\circ} \mathrm{C}$ for fungi. Sera from culturenegative patients were examined for $Q$ fever antibodies. Antibiotic sensitivities were assessed for organisms isolated and the minimum inhibitory concentration of each agent was estimated when possible as described by Jawetz (1962). The minimum accepted bactericidal level of 1 in 8 was measured at the 'trough' time interval in relation to the previous dose.
Twenty-three patients developed prosthetic endocarditis during this time and a review of their case histories forms the material for this paper.

\section{Results}

\section{INCIDENCE}

Twenty-four episodes of endocarditis occurred in 23 patients. The number of cases occurring early and late after surgery in each of the 10 years are shown in Table 1. Operative and clinical data on both groups are presented in Table 2 . The inci-

Table 1 Numbers of operations and early and late cases occurring each year

\begin{tabular}{lllll}
\hline \multirow{2}{*}{ Year } & \multirow{2}{*}{$\begin{array}{l}\text { No. of } \\
\text { operations }\end{array}$} & \multicolumn{2}{l}{ Endocarditis } \\
\cline { 3 - 5 } & & Early & Late & Total \\
\hline 1966 & 92 & 1 & 0 & 1 \\
1967 & 101 & 0 & 0 & 0 \\
1968 & 110 & 1 & 1 & 2 \\
1969 & 89 & 0 & 0 & 0 \\
1970 & 123 & 3 & 1 & 4 \\
1971 & 83 & 5 & 0 & 5 \\
1972 & 57 & 1 & 1 & 2 \\
1973 & 79 & 1 & 3 & 4 \\
1974 & 118 & 1 & 1 & 2 \\
1975 & 87 & 2 & 2 & 4 \\
\hline
\end{tabular}

Table 2 Preoperative details of 24 patients, time of presentation after surgery, postoperative course of early group, and possible sources of infection in late group

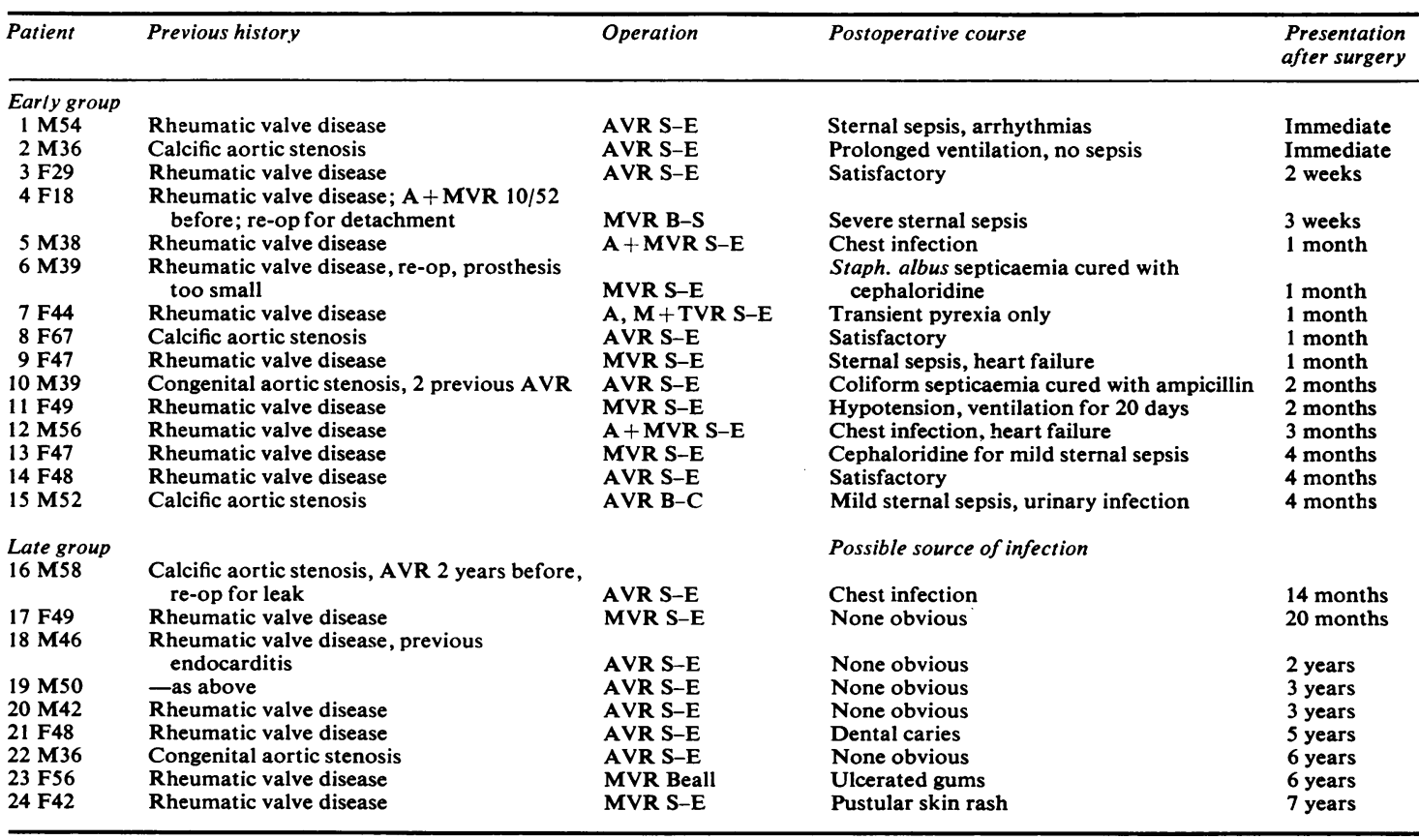

AVR-aortic valve replacement; MVR-mitral valve replacement; TVR-tricuspid valve replacement; B-S-Björk-Shiley; S-E-Starr Edwards; B-C-Braunwald Cutter. 
dence of $1.7 \%$ of endocarditis occurring early after operation in this series does not take into consideration an outbreak of Aspergillus prosthetic endocarditis which developed during the decade under review because rather than being sporadic infections these were a consequence of inadequate maintenance of the operating theatre ventilation system (Petheram and Seal, 1976) and attention to the common source of contamination prevented the occurrence of further cases. The incidence of late cases was $1 \%$. The average age of the men (45.5 years, range 36-58) and the women (45.0 years, range 18-67) was the same as the average age for all patients receiving valve replacements during this period.

\section{OPERATIONS}

In 18 patients valve replacement was required for rheumatic valve disease and in six for isolated aortic stenosis (Table 2). No patient needed operation for active infection, only one having a previous history of infective endocarditis (case 18). In four patients the operation was revision valve replacement (cases $4,6,16,19$ ) and in one (case 10) aortic valve surgery for the third time. The types of valves inserted in each patient are shown in Table 2. Two patients had double valve replacements and one a triple replacement, the Starr Edwards ball valve being used in all positions. In two patients mitral valvotomy was performed in addition to valve replacement. There was no difference in the mean duration of operation for single, double or triple valve replacement of the other patients in this series compared with other similar operations, and no apparent relationship was observed between the size of prosthesis and the development of endocarditis.

The early postoperative course of patients developing endocarditis was satisfactory in only three. Two patients required prolonged assisted ventilation for respiratory insufficiency, five had sternal sepsis ranging from severe (case 4) to mild (cases 13 and 15), and two suffered lower respiratory tract infections requiring short courses of additional antibiotics. Two patients were treated for septicaemia caused by Staphylococcus albus (case 6) and a coliform (case 10), and both were considered cured after a two-week course of antibiotics.

\section{PRESENTATION}

Although the onset of illness was sometimes difficult to determine from postoperative complications, two clear groups emerged, 15 presenting up to four months after surgery and nine more than a year later (range 14 months to 7 years). The incidence of important clinical and laboratory features is shown in Table 3. Cardiac failure was more 7 common in the early group but the other findings occurred with equal frequency in either group. The commonest combination was pyrexia, anaemia, raised sedimentation rate, and heart failure. Fever varied from a low-grade intermittent pattern to a high continuous type. Anaemia was also variable, the haemoglobin being in the range 9-12 g/dl except when mechanical haemolysis was present. The sedimentation rate was invariably raised, between 40 and over $100 \mathrm{~mm}$ in the first hour, in those patients for whom information was available. Included in the term 'embolism' are those peripheral lesions which are considered immunological in origin. Sites commonly involved were abdominal organs, particularly the spleen, and brain and retina. 'Osler's nodes' were noted in four patients.

Table 3 Frequency of important clinical and laboratory findings

\begin{tabular}{llll}
\hline Feature & Present & Absent & Not known \\
\hline Fever & 24 & 0 & 0 \\
Anaemia & 24 & 0 & 0 \\
RBC in urine & 23 & 1 & 0 \\
Raised ESR & 21 & 0 & 3 \\
Raised WBC & 17 & 6 & 1 \\
Heart failure & 17 & 7 & 0 \\
'Embolism' & 16 & 8 & 0 \\
New murmurs & 10 & 14 & 0 \\
Splenomegaly & 10 & 14 & 0 \\
Petechiae & 7 & 16 & 1 \\
\hline
\end{tabular}

\section{BACTERIOLOGY}

In three patients the infections were mixed, Candida albicans being involved in all. In patient 9 , 'cocci' were identified histologically but could not be classified, and in patient 16 no organisms were identified although endocarditis was certain histologically. All other cases were caused by single organisms. The commonest organisms causing in- $\frac{\rho}{2}$ fection early after surgery were diphtheroid species $\frac{D}{O}$ and $C$. albicans and the bacteriological details of patients in the early group are shown in Table 4 . N In nine patients the infecting organism was isolated by routine swabs or cultures from an extracardiac site of sepsis often before blood cultures $\omega$ were positive. In four patients (cases $4,6,10$, and 12) the organism caused endocarditis despite being $\varrho$ sensitive in vitro to the prophylactic antibiotic $\mathbb{D}$ cover, and in two others the pathogen was sensi- tive to an antibiotic used for postoperative infec- $\frac{T}{3}$ tive complications. In the late group the $\underset{\mathbb{D}}{\circ}$ commonest organisms causing infection were streptococci. 
Table 4 Bacteriological details of patients presenting early after surgery

\begin{tabular}{|c|c|c|c|c|}
\hline Patient & Organism & $\begin{array}{l}\text { Perioperative antibiotic, prophylaxis } \\
\text { and other therapy }\end{array}$ & Sensitivity in vitro & Potential source \\
\hline 1 & Candida & $\begin{array}{l}\text { Ampicillin, cloxacillin, and chloramphenicol } \\
\text { for sternal sepsis }\end{array}$ & No & Sputum \\
\hline 2 & Candida & Ampicillin and cloxacillin, Cotrimoxazole later & No & Sputum \\
\hline 3 & Diphtheroid & Cloxacillin & Not tested & None obvious \\
\hline 4 & Staph. aureus & Ampicillin and cloxacillin & Yes & Sternotomy wound \\
\hline 5 & Staph. aureus & $\begin{array}{l}\text { Ampicillin, } \\
\text { cotrimoxazole later for chest infection }\end{array}$ & $\begin{array}{l}\text { No } \\
\text { Not tested }\end{array}$ & None obvious \\
\hline 6 & Klebsiella & Tetracycline & Yes & Sputum, urine \\
\hline 7 & $\begin{array}{l}\text { Candida, } \\
\text { Proteus, coliform }\end{array}$ & $\begin{array}{l}\text { Ampicillin and cloxacillin, } \\
\text { chloramphenicol later for chest infection }\end{array}$ & $\begin{array}{l}\text { Candida-no } \\
\text { Proteus, coliform-yes }\end{array}$ & Sputum, urine \\
\hline 8 & Diphtheroid & Cloxacillin & Not tested & None obvious \\
\hline 9 & 'Cocci' & Cloxacillin & Unknown & Sternal sepsis \\
\hline 10 & Alcaligenes faecalis & $\begin{array}{l}\text { Ampicillin and cloxacillin, } \\
\text { ampicillin later for septicaemia }\end{array}$ & $\begin{array}{l}\text { Ampicillin sensitive } \\
\text { Cloxacillin not tested }\end{array}$ & Urine \\
\hline 11 & $\begin{array}{l}\text { Diphtheroid } \\
\text { Candida }\end{array}$ & Ampicillin and cloxacillin & $\begin{array}{l}\text { Candida-no } \\
\text { Diphtheroid ampicillin resistant } \\
\text { cloxacillin not tested }\end{array}$ & Sputum, urine \\
\hline 12 & $\begin{array}{l}\text { Candida } \\
\text { Staph. aureus }\end{array}$ & Ampicillin and cloxacillin & $\begin{array}{l}\text { No } \\
\text { Yes }\end{array}$ & Sputum, urine \\
\hline 13 & Diphtheroid & Cloxacillin & Not tested & None obvious \\
\hline 14 & Diphtheroid & Ampicillin and cloxacillin & $\begin{array}{l}\text { Ampicillin resistant, } \\
\text { cloxacillin not tested }\end{array}$ & None obvious \\
\hline 15 & Strep. faecalis & $\begin{array}{l}\text { Cloxacillin, } \\
\text { cotrimoxazole later for urinary infection }\end{array}$ & No & Sternotomy wound \\
\hline
\end{tabular}

\section{IDENTIFICATION OF ORGANISM}

Blood cultures were positive in all patients cured and in eight of the 13 who died. Except in two patients ( 8 and 24), if cultures were positive the first set of culture bottles inoculated revealed the organism. There was a long delay before cultures became positive in patient 8 , and in patient 24 Staph. albus was eventually cultured from arterial samples taken from near the mitral valve by retrograde left-heart catheterisation after 16 sets of venous culture were negative. The organism was cultured or identified histologically at necropsy in all fatal cases when antibacterial therapy had been given for only a short time (four to nine days) before death. In patients who had received long courses (three to six weeks) of antibiotics before death (cases 10,13,16,18, and 23) necropsy failed to reveal the infecting agent.

\section{TREATMENT AND OUTCOME}

Five of the 15 early cases and six out of nine late cases were cured. Details of treatment are shown in Table 5 for those patients cured and in Table 6 for patients who died. The mean time from presentation to the start of treatment was 14 days for the patients cured and 26 for those who died. Causes of death are shown in Table 6. The pathogen was not isolated in five patients and found only late in the course of the illness in three others so that either no therapy was given, or it was 'blind' and too late to affect the outcome. In five patients $(10,13,16,19$, and 23$)$ the treatment appears to have been adequate initially, the causes of death being haemodynamic faults in four and cerebral haemorrhage in one. Only one of the five patients infected with $C$. albicans was cured, two of the others receiving no treatment at all. Three of the five patients infected with diphtheroids and two out of four patients infected with Staph. aureus and with Streptococcus viridans were cured.

\section{RELAPSES}

Four patients $(15,17,20$, and 22$)$ received a course of antibiotics that appeared successful but relapse occurred on withdrawal of treatment, blood cultures becoming positive immediately. Further courses of antibiotics, alone in patient 15 and with reoperation in the other three, achieved cure.

\section{REOPERATION}

Five patients had revision valve replacements, two because of heart failure after the infection was cured (18 and 21) and three because of difficulty in overcoming infection. Four of these operations were successful; the fifth (patient 21 ) had a successful replacement but died in the convalescent period due to dehiscence of the aortotomy site. There was no evidence of endocarditis at necropsy.

\section{Discussion}

This series confirms previous reports that two separate groups of prosthetic valve endocarditis occur (Shafer and Hall, 1970; Dismukes et al., 1973) but we do not agree that an arbitrary time of 
Table 5 Details of treatment in patients cured

\begin{tabular}{|c|c|c|c|c|}
\hline Patient & Organism & $\begin{array}{l}\text { Isolated by blood } \\
\text { culture }\end{array}$ & $\begin{array}{l}\text { Time between } \\
\text { presentation and } \\
\text { therapy }\end{array}$ & Chemotherapy \\
\hline 3 & Diphtheroid & Yes & 12 days & $\begin{array}{l}\text { Flucloxacillin and cephalothin, later cotrimoxazole, } \\
\text { clindamycin, and fusidic acid }\end{array}$ \\
\hline 5 & Staph. aureus & Yes & 4 days & $\begin{array}{l}\text { Cloxacillin, ampicillin, cephaloridine, and streptomycin- } \\
\text { total } 2 \text { months }\end{array}$ \\
\hline 11 & Diphtheroid & Yes & 10 days & $\begin{array}{l}\text { Cephalexin, cephaloridine, gentamicin, and clindamycin- } \\
\text { total } 6 \text { weeks; } 5 \text {-fluorocytosine for } 2 \text { months }\end{array}$ \\
\hline 14 & Diphtheroid & Yes & 3 weeks & $\begin{array}{l}\text { Ampicillin for } 1 \text { week; penicillin, streptomycin, later } \\
\text { cephaloridine for } 6 \text { weeks }\end{array}$ \\
\hline 15 & $\begin{array}{l}\text { Strep. faecalis } \\
\text {-relapse }\end{array}$ & $\begin{array}{l}\text { Yes } \\
\text { Yes }\end{array}$ & $\begin{array}{l}1 \text { week } \\
\text { immediate }\end{array}$ & $\begin{array}{l}\text { Erythromycin and cotrimoxazole for } 6 \text { weeks } \\
\text { Erythromycin and cotrimoxazole for } 2 \text { weeks } \\
\text { Ampicillin and gentamicin for } 2 \text { months }\end{array}$ \\
\hline 17 & $\begin{array}{l}\text { Staph. aureus } \\
\text {-relapse }\end{array}$ & Yes & $\begin{array}{l}1 \text { day } \\
\text { immediate }\end{array}$ & $\begin{array}{l}\text { Penicillin and cloxacillin for } 2 \text { months } \\
\text { Cloxacillin and re-operation }\end{array}$ \\
\hline 18 & Strep. viridans & Yes & unknown & Penicillin for 6 weeks \\
\hline 20 & $\begin{array}{l}\text { Neisseria catarrhalis } \\
\text { - relapse }\end{array}$ & $\begin{array}{l}\text { Yes } \\
\text { Yes }\end{array}$ & $\begin{array}{l}8 \text { weeks } \\
\text { immediate }\end{array}$ & $\begin{array}{l}\text { Penicillin, streptomycin, and cotrimoxazole for } 2 \text { months } \\
\text { Cotrimoxazole, gentamicin, and re-operation }\end{array}$ \\
\hline 21 & Strep. viridans & Yes & 1 week & Penicillin, streptomycin for 6 weeks \\
\hline 22 & $\begin{array}{l}\text { Diphtheroid } \\
\text {-relapse }\end{array}$ & $\begin{array}{l}\text { Yes } \\
\text { Yes }\end{array}$ & $\begin{array}{l}3 \text { days } \\
\text { immediate }\end{array}$ & $\begin{array}{l}\text { Erythromycin and fusidic acid for } 4 \text { weeks } \\
\text { Ampicillin and streptomycin for } 4 \text { weeks and re-operation }\end{array}$ \\
\hline 24 & Staph. albus & Yes & 2 weeks & Cloxacillin and gentamicin for 2 months \\
\hline
\end{tabular}

Table 6 Details of treatment in patients who died and reasons for death

\begin{tabular}{|c|c|c|c|c|c|c|}
\hline \multirow[t]{2}{*}{ Patient } & \multirow[t]{2}{*}{ Organism } & \multicolumn{2}{|c|}{ Organism isolated } & \multirow{2}{*}{$\begin{array}{l}\text { Time between } \\
\text { presentation } \\
\text { and therapy }\end{array}$} & \multirow[t]{2}{*}{ Chemotherapy } & \multirow[t]{2}{*}{ Reason for failure } \\
\hline & & Blood culture & Necropsy & & & \\
\hline 1 & Candida & No & Yes & 6 weeks & Clotrimazole for 4 days & $\begin{array}{l}\text { Organism not isolated in life; } \\
\text { treatment too late }\end{array}$ \\
\hline 2 & Candida & Yes & Yes & - & None & $\begin{array}{l}\text { Organism not isolated until day } \\
\text { of death; no treatment }\end{array}$ \\
\hline 4 & Staph. aureus & Yes & Yes & 2 days & $\begin{array}{l}\text { Cloxacillin, gentamicin } \\
4 \text { days }\end{array}$ & Overwhelming sepsis \\
\hline 6 & Klebsiella & Yes & Yes & 9 days & $\begin{array}{l}\text { Gentamicin and cotri- } \\
\text { moxazole for } 6 \text { days } \\
\text { Carbenicillin }\end{array}$ & $\begin{array}{l}\text { Sudden death after } 4 \text { days } \\
\text { therapy - arrhythmia }\end{array}$ \\
\hline 7 & $\begin{array}{l}\text { Candida, Proteus, } \\
\text { coliform }\end{array}$ & No & Yes & 5 weeks & $\begin{array}{l}\text { Gentamicin, kanamycin, and } \\
\text { amphotericin B for } 9 \text { days }\end{array}$ & $\begin{array}{l}\text { Organisms not isolated in life; } \\
\text { mixed infection, blind therapy }\end{array}$ \\
\hline 8 & Diphtheroid & Yes & Yes & 6 weeks & $\begin{array}{l}\text { Cephaloridine and } \\
\text { streptomycin for } 7 \text { days }\end{array}$ & $\begin{array}{l}\text { Organism isolated late, therapy } \\
\text { late, myocardial abscess }\end{array}$ \\
\hline 9 & 'Cocci' & No & Yes & 1 week & $\begin{array}{l}\text { Penicillin and cloxacillin for } \\
2 \text { weeks post-operatively; } \\
\text { no further treatment for } \\
3 \text { months }\end{array}$ & $\begin{array}{l}\text { No organism isolated in life; } \\
\text { initial therapy not adequate }\end{array}$ \\
\hline 10 & Alcaligenes faecalis & Yes & No & 6 days & $\begin{array}{l}\text { Ampicillin and cotrimoxazole } \\
\text { for } 6 \text { weeks }\end{array}$ & $\begin{array}{l}\text { Valve detachment, LVF, } \\
\text { arrhythmia }\end{array}$ \\
\hline 12 & $\begin{array}{l}\text { Staph. aureus } \\
\text { Candida }\end{array}$ & $\begin{array}{l}\text { No } \\
\text { No }\end{array}$ & $\begin{array}{l}\text { Yes } \\
\text { Yes }\end{array}$ & - & None & $\begin{array}{l}\text { Organisms not recovered in life; } \\
\text { no therapy }\end{array}$ \\
\hline 13 & Diphtheroid & Yes & Yes & 2 weeks & $\begin{array}{l}\text { Penicillin and gentamicin } \\
\text { for } 4 \text { weeks }\end{array}$ & Detached valve, LVF \\
\hline 16 & Not identified & No & No & 2 weeks & $\begin{array}{l}\text { Penicillin and gentamicin, } \\
\text { later clindamycin and fusidic } \\
\text { acid }\end{array}$ & $\begin{array}{l}\text { Blind therapy; valve regurgitant } \\
\text { considered inoperable }\end{array}$ \\
\hline 19 & Strep. viridans & Yes & No & 2 weeks & $\begin{array}{l}\text { Penicillin and streptomycin } \\
\text { for } 1 \text { month }\end{array}$ & $\begin{array}{l}\text { Valve regurgitant, haemolysis, } \\
\text { uraemia, probable } \\
\text { bacteriological cure }\end{array}$ \\
\hline 23 & Strep. viridans & Yes & No & 3 days & $\begin{array}{l}\text { Penicillin and streptomycin } \\
\text { for } 3 \text { weeks, later } \\
\text { clindamycin and gentamicin }\end{array}$ & $\begin{array}{l}\text { Cerebral haemorrhage; probable } \\
\text { bacteriological cure }\end{array}$ \\
\hline
\end{tabular}

60 days can be used to differentiate them. Certain problems in diagnosis and management are common to both groups but differences in time of presentation, the greater variety of infecting organisms, and higher mortality in the early compared with the late group suggest that they should be discussed separately.

\section{EARLY GROUP}

There is little indication that early prosthetic in- $\stackrel{\mathbb{D}}{+}$ fection is becoming less frequent since the inci- $\square$ dence of $1.7 \%$ in this series is similar to previous experience (Shafer and Hall, 1970). The infections $\stackrel{\mathbb{D}}{\Omega}$ were sporadic, suggesting several portals of entry, $\stackrel{\mathbb{}}{\varnothing}$ and no common source was identifiable. 
One diagnostic problem is that positive blood cultures may not imply involvement of the prosthesis. Sande et al. (1972) have suggested that bacteraemia in the early postoperative period is unlikely to mean endocarditis if the organisms are Gram-negative, if there is an extracardiac site of infection, and if no new murmurs develop. Dismukes et al. (1973) do not agree with this suggestion because they found valve involvement in four of their five cases of Gram-negative bacteraemia occurring soon after operation. Madison et al. (1975) also reported two cases of valve involvement when cultures produced Gram-negative organisms. We suggest that the prosthesis must be assumed to be infected and that the shorter courses of treatment suggested by Sande et al. (1972) are not adequate. One of our patients was given a two-week course of treatment for 'bacteraemia' caused by Alkaligenes faecalis but presented later with obvious valve involvement and died from the haemodynamic consequence of valve detachment. The common clinical and laboratory features occurring in our patients were not helpful since fever, anaemia, raised sedimentation rate, and heart failure in patients convalescing from valve replacement surgery usually have other explanations. Isolation of a pathogen from blood culture is, therefore, vital for a successful outcome. Of the 10 patients from this group who died, the commonest reason for death was a delay or inability to culture the organism, so that uncontrolled infection causing valve detachment with cardiac failure was often the mode of death. These patients had received courses of antibiotics previously.

A patient who is deteriorating with an illness suggestive of infective endocarditis but with negative blood cultures presents a dilemma. To embark on 'blind' therapy is generally recommended (Oakley, 1974) but there is no way of monitoring minimum bactericidal concentrations, and results are, therefore, likely to be poor. In the absence of clinical deterioration it may be worth waiting to obtain more blood samples for culture or to perform special procedures, as in patient 24 , but our findings generally support those of Hayward (1973) and Oakley (1974) that if a pathogen is isolated it appears in the first few sets of cultures. If a regimen of antibiotics has to be selected for a culture-negative patient with endocarditis we suggest that close attention should be paid to extracardiac sites of infection, such as respiratory, urinary or sternal sepsis, since the eventual pathogen was present at these sites in nine out of the 15 patients either in the early postoperative period or when the patient presented later.

The common organisms causing early prosthetic endocarditis in this series, Diphtheroid sp and $C$. albicans, differ from the staphylococcal species which predominated in previous reported series (Braimbridge, 1969). The low incidence of staphylococcal endocarditis, three cases out of 940 operations, suggests that the antistaphylococcal prophylaxis has been fairly successful. The emergence of opportunist organisms of low virulence in health as pathogens in endocarditis is important since they may be overlooked as contaminants in initial culture samples. C. albicans is now a common pathogen after cardiac surgery (Engelman et al., 1973), and for cure antifungal chemotherapy plus revision valve replacement has usually been necessary (Warner et al., 1971; English and Ross, 1972). Only one patient in the present series who was infected with $C$. albicans was cured and she was of interest in that the fungus was a second infecting organism complicating diphtheroid endocarditis and also because cure was achieved without further surgery. A second pathogen should always be suspected if a patient deteriorates while on treatment that caused initial improvement (Boyce, 1975). The frequency of diphtheroid endocarditis found in this series has not been observed in other series although Jackson and Saunders (1973) reported seven examples and between 1964 and 1971 but they gave no data on other pathogens during this period. Ampicillin was added to the operative prophylactic cover in the middle of the 10 years under review, since diphtheroids were frequently recovered from routine culture plates monitoring the operating environment, but in two patients diphtheroid species causing endocarditis were resistant to ampicillin and in three others where cloxacillin alone was given this did not prevent prosthetic infection. In three out of the six cases of diphtheroid endocarditis occurring within a year of surgery reported by Jackson and Saunders (1973), the organism was also resistant to ampicillin and cloxacillin. We suggest that there should be constant bacteriological surveillance of both the operating and intensive care environment to detect the emergence of resistant strains. Several combinations of antibiotics were tried to treat diphtheroid endocarditis. Although we have concluded that a combination of erythromycin and fusidic acid seems particularly effective, as Jackson and Saunders (1973) have described, four weeks on this regimen did not prevent relapse in one patient (case 22).

Early prosthetic endocarditis can be cured by antibiotics alone. Five of 15 patients in our early 
group and four out of six cures in the early group of Dismukes et al. (1973) recovered after long courses of antibiotics. Valve replacement in addition to long courses of chemotherapy may have saved two more of our patients (cases 10 and 13), and in view of favourable reports of valve replacement in active endocarditis (Okies et al., 1970; English and Ross, 1972) we would advocate a more aggressive surgical approach in the future.

\section{LATE GROUP}

Late-onset prosthetic valve endocarditis is less common and has a different bacteriological spectrum and a better prognosis than the early type. The small number of reports has been emphasised by Dismukes et al. (1973), who analysed 19 cases, the largest series published so far. The pathogens and mortality rate in our series are similar to those of classical infective endocarditis. Four of our nine cases were caused by Strep. viridans, the probable portal of entry being the oral cavity in two. Whether the patients had prior dental manipulation with or without antibiotic cover is not known. We agree with Madison et al. (1975) that dental and oral hygiene and antibiotic cover for all manipulations is as important after valve replacement as it is before operation. Recent work has suggested that penicillin combined with an aminoglycoside may be better than penicillin alone (Durack and Petersdorf, 1973; Durack, 1975).

Six of the nine patients were cured, which compares favourably with the series reported by Dismukes et al. (1973). Four of the patients required replacement of the infected prosthesis because antibiotic therapy alone did not overcome the infection. None of these patients developed septicaemia or prosthetic infection postoperatively so surgery for uncontrolled infection is less hazardous than was previously thought (Okies et al., 1971). It is disappointing that two of the patients in the late group who died were infected with Strep. viridans despite long courses of treatment. Death was caused by cerebral haemorrhage in one and progressive valvar regurgitation with haemolysis in the other. Surgery may have saved this man. It is of interest that in both these patients the vegetations at necropsy were sterile, suggesting that chemotherapy had been adequate. Although antibiotics alone can cure prosthetic endocarditis, death may occur unpredictably from cerebral embolism or more predictably from progressive heart failure which should be an indication for surgical intervention.

A number of general problems are common to both groups of prosthetic endocarditis. After isolation of the infecting organisms and selection of an antibiotic regimen the response to treatment should be monitored by back titration of the treated plasma against the pathogen. The sedimentation rate and temperature seem to be sensitive indices of resfonse to treatment, and, in our experience, the clinical response closely mirrors in vitro minimum bactericidal levels. The length of treatment required for this condition has not been established and probably varies from case to case. It has been our policy to treat with a combination of antibiotics administered intravenously until the temperature remains normal for six weeks. This sometimes involves eight weeks' therapy, and the most acceptable way of administering the drugs in our view is by bolus injection into an intravenous line placed in the superior vena cava inserted via a subclavian vein. The patient thereby retains mobility and full use of the upper limbs. The line is kept patent by a dextrose infusion or a dilute heparin solution. There have been no important septic or thrombotic complications of this technique.

Anticoagulants have not been shown to reduce embolic complications in infective endocarditis and are generally contraindicated (Dorney, 1974). Patients with infective endocarditis on prosthetic cardiac valves present a different problem since they are nearly all already anticoagulated. Windsor et al. (1968) described intra-atrial thrombosis associated with infection on mitral prostheses in nine patients and regarded anticoagulation as an essential part of the management. All except one of our patients were taking oral anticoagulants, dipyridamole being considered adequate protection in the other. In a further patient (case 17), anticoagulants were stopped shortly after diagnosis because of haematuria but 10 days later she suffered a series of cerebral emboli. Anticoagulants were restarted and there were no further cerebral incidents. The policy in the other patients was to maintain the prothrombin time between one and $\widetilde{N}$ a half to twice normal, and only one patient $N$ suffered cerebral haemorrhage, the precise cause $\mathcal{O}_{\mathrm{S}}$ not being established at necropsy. Of nine patients $\omega$ described by Block et al. (1970), one had a cerebral embolism when anticoagulation was with- $\stackrel{\circ}{=}$ drawn and another died of cerebral haemorrhage $\Phi$ when the prothrombin time was 40 seconds. While accepting that there are some risks, there seems no reason to discontinue anticoagulants routinely $\mathbb{D}$ in patients with prosthetic endocarditis, provided $\frac{\Omega}{\mathrm{D}}$ the prothrombin time is meticulously controlled.

A reduction in the number of cases of prosthetic 
endocarditis of both types may be achieved by careful attention to prophylactic antibiotic regimens in the early group and greater awareness of the risks of dental, urinary, and respiratory infection in the late group but cases are still likely to occur. In the management of these patients we suggest that close liaison between clinical bacteriologist and clinician and early surgical intervention for haemodynamic complications or failure to control infection will reduce the mortality in both groups.

We thank Mr. T. H. L. Rosser, Mr. D. M. E. Thomas, Mr. H. R. S. Harley, Mr. I. M. Breckenridge, Dr. A. J. Thomas, and Dr. L. G. Davies for permission to study their patients and for helpful advice, and Miss Pat Edwards for typing the manuscript.

\section{References}

Block. P. C., DeSanctis, R. W., Weinberg, A. N., and Austen, W. G. (1970). Prosthetic valve endocarditis. Journal of Thoracic and Cardiovascular Surgery, 60, 540-548.

Boyce, J. M. H. (1975). A case of prosthetic valve endocarditis caused by Corynebacterium hofmanni and Candida albicans. British Heart Journal, 37, 1195-1197.

Braimbridge, M. V. (1969). Cardiac surgery and bacterial endocarditis. Lancet, 1, 1307-1309.

Denton, C., Pappas, E. G., Uricchio, J. F., Goldberg, H., and Likoff, W. (1957). Bacterial endocarditis following cardiac surgery. Circulation. 15, 525-531.

Dismukes, W. E., Karchmer, A. W., Buckley, M. J., Austen, W. G., and Swartz, M. N. (1973). Prosthetic valve endocarditis. Circulation, 48, 365-377.

Dorney, E. R. (1974). Diseases of the endocardium. In The Heart, edited by J. Hurst and R. B. Logue, 2nd edition, chapter 69, p. 1290. McGraw-Hill, New York.

Durack, D. T. (1975). Current practice in prevention of bacterial endocarditis. British Heart Journal, 37, 478-481.

Durack, D. T. and Petersdorf, R. G. (1973). Chemotherapy of experimental streptococcal endocarditis. I. Comparison of commonly recommended prophylactic regimens. Journal of Clinical Investigation, 52, 592-598.

Engelman, R. M., Chase, R. M., Jr., Boyd, A. D., and Reed, G. E. (1973). Lethal postoperative infections following cardiac surgery. Circulation, 47/48, supplement III, 31-36.

English, T. A. H. and Ross, J. K. (1972). Surgical aspects of bacterial endocarditis. British Medical Journal, 4, 598-602.

Hayward, G. W. (1973). Infective endocarditis: A changing disease. British Medical Journal, 2, 706709, 764-766.

Jackson, G. and Saunders, K. (1973). Prosthetic valve diphtheroid endocarditis treated with sodium fusidate and erythromycin. British Heart Journal, 35, 931-936.

Jawetz, E. (1962). Assay of antibacterial activity in serum. A useful guide for complex antimicrobial therapy. American Journal of Diseases of Children, 103, 81-84.

Lord, J. W., Jr., Imparato, A. M., Hackel, A., and Doyle. E. F. (1961). Endocarditis complicating open-heart surgery. Circulation, 23, 489-497.

Madison, J., Wang, K., Gobel, F. L., and Edwards, J. E. (1975). Prosthetic aortic valvular endocarditis. Circulation. 51, 940-949.

Oakley, C. M. (1974). Infective endocarditis. British Journal of Hospital Medicine, 11, 101-108.

Okies, J. E., Viroslav, J., and Williams, T. W., Jr. (1971). Endocarditis after cardiac valvular replacement. Chest. 59, 198-202.

Okies, J. E., Williams, T. W., Jr., Howell, J. F., Crawford, E. S., Morris, G. C., and DeBakey, M. E. (1970). Valvular replacement in bacterial endocarditis. Cardiovascular Research Centre Bulletin, 8, 126-134.

Petheram, I. S. and Seal, R. M. E. (1976). Aspergillus prosthetic valve endocarditis. Thorax, 31, 380-390.

Sande, M. A., Johnson, W. D., Jr., Hook, E. W., and Kaye, D. (1972). Sustained bacteremia in patients with prosthetic cardiac valves. New England Journal of Medicine, 286, 1067-1070.

Shafer, R. B. and Hall, W. H. (1970). Bacterial endocarditis following open heart surgery. American Journal of Cardiology, 25, 602-607.

Slaughter, L., Morris, J. E., and Starr, A. (1973). Prosthetic valvular endocarditis, a 12 year review. Circulation, 47, 1319-1326.

Stein, P. D., Harken, D. E., and Dexter. L. (1966). The nature and prevention of prosthetic valve endocarditis. American Heart Journal, 71, 393-407.

Warner. J. F., McGehee, R. F., Duma, R. J.. Shadomy, S., and Utz, J. P. (1971). 5-fluorocytosine in human candidiasis. Antimicrobial Agents and Chemotherapy (1970), 473-475.

Windsor, H. M., Fagan, P., and Shanahan, M. X. (1968). Bacterial endocarditis, mitral regurgitation, and intra-atrial thrombosis following mitral valve replacement. Thorax, 23, 11-18.

Requests for reprints to: Dr. I. S. Petheram, Brompton Hospital, Fulham Road, London SW3 6HP. 